\title{
TOWARDS SAFER SEAFOOD: WHAT INDONESIAN LAW SHOULD "SAY" ABOUT MERCURY-CONTAMINATED FISH
}

\author{
Margaretha Quina
}

* Indonesian Center for Environmental Law (ICEL)

\begin{abstract}
Article Info
Received : 16 December 2015 | Received in revised form : 11 July 2016 | Accepted : 16 August 2016

Corresponding author's e-mail : margaretha.quina@icel.or.id
\end{abstract}

\begin{abstract}
Fish is a popular culinary dish in Indonesian culture and a major economic resource on which many people depend their livelihood. However, with severe pollution in Indonesian water, including uncontrolled mercury pollution which persists in the food chain and eventually gets into humans' body as the top predator, fish safety is particularly worrying - especially taking into account the frequency of average Indonesians' consumption of fish. In various jurisdictions, the management tool used by lawmakers and regulators with regard to this issue is information disclosure, or known as "fish advisory warning," to cover the failure of command and control. This paper analyses whether Indonesian laws have provided the mandate or authority to issue fish advisory warning under Fishery Law, Food Law, Environmental Protection and Management Law, and Public Information Disclosure Law. It concluded that Indonesian law implies a statutory mandate for the government to issue fish advisory warning, at least in a situation involving the threat to general life - not specifically through the Fishery Law, Food Law, or EPML, but through PIDL's immediate information mandate.
\end{abstract}

Keywords: fish advisory warning, information disclosure, environmental justice, mercury, public health.

\begin{abstract}
Abstrak
Ikan adalah kuliner populer dalam budaya Indonesia dan merupakan sumber perekonomian di mana banyak orang menggantungkan penghidupannya. Bagaimanapun, dengan beratnya pencemaran di perairan Indonesia, termasuk pencemaran merkuri yang tidak terkontrol, namun menetap dalam rantai makanan dan pada akhirnya masuk ke tubuh manusia sebagai predator teratas, keamanan pangan ikan cukup mencemaskan - terlebih, mempertimbangkan frekuensi orang Indonesia dalam konsumsi ikan. Di berbagai yurisdiksi, alat manajemen yang digunakan oleh pembuat kebijakan dan regulator terkait isu ini adalah keterbukaan informasi, atau dikenal sebagai "peringatan konsumsi ikan," untuk mengantisipasi kegagalan instrumen pengendalian. Artikel ini menganalisis apakah hukum Indonesia telah mewajibkan atau memberikan kewenangan untuk melakukan peringatan konsumsi ikan dalam UU Perikanan, UU Pangan, UU Perlindungan dan Pengelolaan Lingkungan Hidup, dan UU Keterbukaan Informasi Publik. Artikel ini menyimpulkan bahwa hukum Indonesia menyiratkan mandat hukum bagi pemerintah untuk melakukan peringatan konsumsi ikan, setidaknya dalam situasi yang melibatkan ancaman ke kepentingan umum - tidak secara spesifik dalam UU Perikanan, UU Pangan, ataupun UU PPLH, namun melalui UU KIP.
\end{abstract}

Kata Kunci: peringatan konsumsi ikan, keterbukaan informasi, keadilan lingkungan, merkuri, kesehatan publik. 


\section{Introduction}

As an archipelagic state surrounded by seas and oceans, one of Indonesia's most abundant natural resources is fish. Not only abundant, fish also hold a special place in the life of Indonesians: fish is a big part of the nation's diet, part of its cultural pride, and one of the most important economic resources. ${ }^{1}$ However, Indonesia is also abundant with the fish' biggest enemy: mercury. With the government's failure to control small scale gold mining and coal power plant mercury emission, Indonesia ended up being one of the world's largest users of mercury. ${ }^{2}$ That is exactly what triggers a global public health concern: as a persistent pollutant, mercury remains through the food chain, and eating contaminated fish means accumulating mercury to humans' body - until the point its amount reaches non-tolerable concentration and intervenes with the nerve system. ${ }^{3}$ Numerous rejections towards Indonesian fisheries products have taken place, including one of its considerable export commodities, tuna, by developed countries such as Japan, U.S., and the European Union. The reason is the concentration of mercury in the fish surpasses the maximum limit required by the export destinations. ${ }^{4}$ While the nations abroad have measures to control the quality of fish, measures in domestic level is, ironically, less stringent.

Fish consumption advisory is one of the tools that the government can use to inform domestic consumers about the danger related to contaminated fish consumption. ${ }^{5}$ Sadly enough, there is neither such express provision nor government practice in the fisheries legal framework on fish advisory warning. Indonesian substantivelaws related to fishery, including consumer protection law, ${ }^{6}$ public health law, ${ }^{7}$ environmental law, ${ }^{8}$

\footnotetext{
${ }^{1}$ Bruce Glassburner, The Economy of Indonesia: Selected Reading (Sheffield: Equinox Publishing, 2007), p. 158.

2 From year to year, Indonesia's data on mercury export varied greatly from the exporters' database. For example, in 2012, UNCOMTRADE recorded 368 metric tons mercury was legally exported to Indonesia, while the government's statistic edshowed less than 1 metric ton. See: United Nations Commodity Trade Statistic, "Mercury Trade Database," http://comtrade.un.org, accessed March 2015. See also: ZOI Environment Network, "Mercury Trade Map 2011," http://www.zoinet.org/web/sites/default/files/publications/ MercuryTradeMap2011.pdf., accessed on March 25, 2015.

3 UNEP, Global Mercury Assessment 2013: Sources, Emissions, Releases and Environmental Transport (Geneva: UNEP Chemicals Branch, 2013), p. 26-9.

${ }^{4}$ Pusat Kebijakan Regional dan Bilateral Kementerian Keuangan RI dan Program Studi Kajian Wilayah Eropa Program Pascasarjana Universitas Indonesia, Kajian Kerja Sama Bilateral Indonesia - Uni Eropa: Bidang Ekonomi dan Keuangan [Study on Bilateral Partnership between Indonesia - European Union: Economic and Financial Area] (Jakarta, Pusat Kebijakan Regional dan Bilateral Program Studi Kajian Wilayah Eropa Program Pascasarjana Universitas Indonesia, 2012).

5 Plunkett, David and Caroline Smith De Waal. "Who is Responsible for the Safety of Food in a Global Market? Government Certification v. Importer Accountability as Models for Assuring the Safety of Internationally Traded Foods," Food and Drug Law Journal 63 (2008), pp. 657-664.p

6 Indonesia, Undang-Undang tentang Perlindungan Konsumen (Law Regarding Consumer Protection), UU No. 8 Tahun 1999, LN No. 42 Tahun 1999 (Law No. 8 of 1999, SG No. 42 of 1999) ("Consumer Protection Law")

${ }^{7}$ Indonesia, Undang-Undang tentang Kesehatan (Law regarding Health), UU No. 36 Tahun 2009, LN No. 144 Tahun 2009 (Law No. 36 of 2009, SG No. 36 of 2009) ("Public Health Law")

${ }^{8}$ Indonesia, Undang-Undang tentang Perlindungan dan Pengelolaan Lingkungan Hidup (Environmental Protection and Management Law), UU No. 32 Tahun 2009, LN No. 140 Tahun 2009 (Law No. 32 of 2009 , SG No. 140 of 2009) (“EPML"); see also Indonesia, Peraturan Pemerintah tentang Pengelolaan Kualitas Air dan Pengendalian Pencemaran Air (Government Regulation regarding Water Quality Protection and Water Pollution Control), PP No. 82 Tahun 2001, LN No. 153 Tahun 2001 (GR no. 82 of 2001, SG No. 153 of 2001) ("WPC Regulation")
} 
fishery law ${ }^{9}$ and food law, ${ }^{10}$ contain no textual mandate regarding fish advisory warning related to fish with mercury or other toxic contaminants, and each statute has different focus. ${ }^{11}$ Another relevant law is the public information law $^{12}$ which mandates the government to provide information in situations threatening the lives of many people, in an accessible and understandable manner. ${ }^{13}$

This paper aims to provide a thorough analysis of how Indonesian fishery-related laws presently accommodate, and how they should mandate and regulate fish advisory warning as one of the legal tools in protecting public health and the environment. The first part of the paper will examine the logic behind fish advisory warning and how it can contribute to the protection of public health and environment, as well as environmental justice concern related to fish advisory warning. The second part will examine the overall regulatory scheme in Indonesian fishery law and which of the existing tools can inform consumers, both retail buyers in the market and subsistence community, about the fish they consume. In this part, four areas of laws are found to be most relevant: fishery law, food law, environmental law, and public disclosure law. The third part will analyze the weaknesses of the existing tools and identify the main problem, and propose a legal and regulatory strategy that the government can make in using the existing legal framework. This paper concludes that Indonesian law implies the statutory mandate for the government to issue fish advisory warning through public disclosure law. However, House of Representatives leaves a broad discretion for agencies to determine how and to what extent such mandate will be carried out.

\section{Fish Advisory Warning for and Environmental Justice}

\section{A. Rationale of Fish Advisory Warning}

As a risk management tool, ${ }^{14}$ fish advisory warning aims primarily to protect public health from the chemical contaminants that are present in the environment and find their pathway to human exposure. ${ }^{15}$ However, the underlying rationale of fish advisory warning is distinguishable from, but arguably a part of, risk reduction strategies, ${ }^{16}$

9 Indonesia, Undang-Undang tentang Perikanan (Law regarding Fishery), UU No. 31 Tahun 2004, LN No. 154 Tahun 2009 (Law No. 31 of 2004, SG No. 154 of 2009); see also Ministry of Maritime Affairs and Fishery Regulation No. PER.19-MEN-2010 regarding Control of Quality Assurance System and Fishery Products Safety ("MMAF Regulation").

10 Indonesia, Undang-Undang tentang Pangan (Law regarding Food), UU No. 18 Tahun 2012, LN No. 227 Tahun 2012 (Law no. 18 of 2012, SG No. 227 of 2012) ("Food Law"); see also Indonesia, Government Regulation no. 28 of 2004 regarding the Safety, Quality and Nutrition of Food; Ministry of Health Regulation No. 2 of 2013 regarding Food Poisoning Outbreak.

${ }^{11}$ Ibid., Art. 46 provides "The government establish and develop fishery information system and statistic data, [...] production, management, and sales of fish, and social-economy data related to fishery management and development of fishery business development"

12 Indonesia, Undang-Undang tentang Keterbukaan Informasi Publik (Public Information Disclosure Law), UU No. 14 Tahun 2008, LN No. 4846 Tahun 2008 (Law No. 14 of 2008, SG No. 4846 of 2008), (“PIDL”); see also Indonesia, Information Commissioner Regulation No. 1 of 2010 regarding Public Information Service Standard ("IC Regulation").

${ }^{13}$ Ibid., art. 10

14 EPA, Risk Assessment: Basic Information, http://www.epa.gov/risk assessment/basicinformation. htm\#a1 accessed on 13 March 2015.

15 See Catherine O’Neill, “No Mud Pies: Risk Avoidance as Risk Regulations," Vermont Law Review 31 (2006-7), p. 276.

${ }^{16}$ Traditionally, risk reduction is understood as measures taken in mitigating the coincidence between 
which focuses on reducing the sources of the risks by putting the burden of reduction to the risk-producers. ${ }^{17}$ Fish advisory warning rather represents the characteristic of risk avoidance ${ }^{18}$ which requires risk-bearers to avoid the risks they face by altering the practices that expose them to the risk. ${ }^{19}$ The core message of advisory, therefore, induces behavioral changes to certain groups of people, especially who are vulnerable to the associated risk, ${ }^{20}$ for example in this case, women who may become pregnant, pregnant women, nursing mothers, young children, or subsistence community. ${ }^{21}$ It discourages or completely bans consumption on certain species the toxicity of which is deemed too high for human health and provides guidance to opt for other safer species, ${ }^{22}$ reduce consumption, ${ }^{23}$ or alter the preparation method in a safer manner. ${ }^{24}$

When the recent trend of the shift from risk reduction to risk avoidance has been a subject to growing number of critics, ${ }^{25}$ in some circumstances, the role of risk avoidance such as fish advisory warning is irreplaceable. ${ }^{26}$ Mercury, a long-range pollutant, has been used widely for a long time in Indonesia, particularly by smallscale gold miners and coal power plants. ${ }^{27}$ On the other hand, mercury has been very

contaminants and human and ecological receptors that might be harmed by contact with the contaminants. Professor O'Neill noted that risk avoidance strategies tend to be discussed as risk reduction strategies, or "included among an undifferentiated menu of 'risk management' options or public health 'intervention."' However, she rejected the idea to treat the two terms (risk reduction and risk avoidance) as similar, rather suggesting the distinction on who bears the burden of reducing the contact of contamination. Risk reduction, in her opinion, aims to "clean up, limit, or prevent environmental contamination by requiring those who are the sources of environmental contamination and the resulting risks to reduce or eliminate the contamination." See Catherine O'Neill, "Risk Avoidance, Cultural Discrimination and Environmental Justice for Indigenous People," Ecology Law Quarterly 30 (2003), pp. 5-7.

17 Risk reduction strategies include imposing clean-up responsibility to risk-producers, and limit and prevent environmental contamination. See NEJAC, Fish Consumption and Environmental Justice, (New Jersey: 2002), p.106.

18 For a comprehensive discussion on how risk reduction and risk avoidance interplay, and how risk reduction strategies could shift to risk avoidance, see O'Neill (2003), op. cit., p. 6.

19 The practices to be altered depend on what "exposure pathways" of certain risks to human, i.e. in terms of fish consumption, subsistence community consumption patterns will require behavioral change in their diet. See Ibid.

${ }^{20}$ Office of Water, EPA, "Guidance for Assessing Chemical Contaminant Data for Use in Fish Advisories," Volume IV: Risk Communication 10 (1995)

${ }^{21}$ EPA, loc. cit. See also U.S. Dept. of Health and Human Servs. \& U.S. EPA, "What You Need to Know About Mercury in Fish and Shellfish," available at http://www.epa.gov/waterscience/fishadvice/advisory. pdf, accessed on 24 March 2015. (hereinafter FDA/EPA Advisory)

${ }^{22}$ For example, FDA/EPA Advisory suggests risk-bearers not to eat shark, swordfish, king mackerel or tilefish at all, while suggesting up to 12 ounces (two average meals) a week of fish and shellfish that are lower in mercury (i.e. shrimp, canned light tuna, salmon, Pollock and catfish), see Ibid.

${ }^{23}$ See 0 'Neill, op.cit., p. 8.

24 For example, California Environmental Protection Agency (Cal EPA) health advisory recommends people eat only fillet portions of fish, and bake, broil, steam or grill fish on a rack so that juices from the fat drip off during cooking. See NEJAC, "Fish Consumption and Environmental Justice: A Report Developed from the National Environmental Justice Advisory Council Meeting," December 3-6, 2001, p. 111.

${ }^{25}$ Some of the critics, as summarized by Prof. O'Neill, argue that agencies have neglected the necessary measures on risk reduction and demonstrated increasing tolerance to rely solely on risk avoidance strategies. She pointed the example of how fish advisory statistics have been increasing in recent years, while there are fish advisory warning that has been in place since 1970s. See O'Neill (2003), op.cit., at 11. See also EPA Office of Water, Guidance for Assessing Chemical Contaminant Data for Use in Fish Advisories, Volume IV: Risk Communication 10 (1995).

${ }^{26}$ See Katherine Renshaw, "Sounding Alarm: Does Informational Regulation Help or Hinder Environmentalism," NYU Environmental Law Journal 14 (2005-6), pp. 679-81.

27 The inventory of mercury release in Indonesia, made by BaliFokus with reference to UNEP's method- 
under-regulated and under-enforced both in the national and local level, ${ }^{28}$ causing methyl-mercury contamination in ecological receptors, including fish, to happen silently without receiving much legal and policy response. ${ }^{29}$ Even if the effective regulation of domestic mercury pollution is finally in place, it will need years to decades to lower the amount of mercury present in fish, if ever. ${ }^{30}$ In between the time period until the contamination can be addressed, fish advisory plays an important role to prevent harm associated with mercury contamination to human. ${ }^{31}$ It is critical to note the nature of advisories should be "temporary and no longer than necessary," ${ }^{32}$ not replacing the risk reduction measures as the primary means to address the contamination. ${ }^{33}$

\section{B. A More Inclusive Advisory: Embracing Environmental Justice}

In addition to its nature as a risk management tool, the advisory also operates as an informational tool, seeking to inform and equip the public with necessary information so they can make a meaningful decision in or alter their behavior in the face of long-term risk. ${ }^{34}$ In theory, information disclosure can help improve efficient functioning of market, ${ }^{35}$ promote individual autonomy, ${ }^{36}$ foster democratic process ${ }^{37}$

ology, concluded that approximately 390,140 kg mercury has been released per year in Indonesia. It identified Artisanal and Small-scale Gold Mining ('ASGM') as the highest source of mercury emission, releasing approximately 195,000 kg mercury annually. See Kania Dewi and Yuyun Ismawati, Inventory of Mercury Releases in Indonesia (Denpasar: Balifokus, 2012); In addition, in 2006, Bandung Geological Resource Center identified 576 hotspots with more than 50,000 miners across Indonesia, while in 2010 the number doubled to 850 hotspots with approximately 150,000 miners. See Yuyun Ismawati, Policy Brief: ASGM in Indonesia (Denpasar: BaliFokus, 2010).

${ }^{28}$ Indonesian Center for Environmental Law, Study on Mercury Regulation in Indonesia (Jakarta: ICEL, 2012).

${ }^{29}$ For example, a research in Tatelu (North Sulawesi Province) confirmed 45\% of 154 fish specimens of 10 freshwater species contain mercury higher than the level set by WHO. See Zuleica C. Castilhos, et. al. "Mercury Contamination in Fish from Gold Mining Areas in Indonesia and Human Health Risk Assessment," Science of the Total Environment 368, issue 1 (September, 2006).

${ }^{30}$ See Renshaw, op.cit., p. 680. In addition to the domestic mercury control, global mercury complicates the problem and remains challenging despite the newly adopted legally binding convention on mercury, Minamata Convention. EPA Mercury Study Report found that even if all global emission of mercury ceased, it would take at least 15 years for the mercury reservoirs in the oceans and the atmosphere to return to the pre-industrial condition. See Office of Air Quality Planning and Standards \& Office of Research and Development, US EPA, Mercury Study Report to Congress, Volume 1: Executive Summary, EPA-452/R-97-003 (1997), pp. 0-1 to 0-2.

31 Ibid., at 681.

32 From the Agencies' (FDA \& EPA's) perspective, advisories are "regrettable or temporary responses to contamination" which should be in place "no longer than necessary." See Elizabeth Southerland, "Proceedings of the National Forum on Contaminants in Fish, May 6 and 9, 2001 1-10 (2001), http://www.epa.gov/ost/fish/forum/fishforum.pdf. accessed on 26 March 2015.

${ }^{33}$ See O’Neill, op.cit., p. 23.

${ }^{34}$ See Renshaw, op.cit., p. 660.

35 Information can equip the public to better bargain the internalization of unaccounted costs of production more effectively. See Daniel C. Esty, "Environmental Protection in the Information Age," NYU Law Review 79, (2004), pp. 115, 117.

${ }^{36}$ Relying on the public's fundamental right to know the risks to which they are being exposed, this argument responses directly to the realization that little or no information about hazardous substances exposures is readily available. It minimizes the people's freedom to make their choices, since people are unaware of the consequences of such uninformed choices. See Susan G. Hadden, A Citizen's Right to Know: Risk Communication and Public Policy, (Boulder, CO: Westview Press, 1989), p. 157.

${ }^{37}$ Forcing disclosure of environmental information to the public can lead to a "democratization" of the 
and provide indirect incentive for industry to undertake self-regulation and thereby reduce risky activity. ${ }^{38}$ However, an informational tool relies on the assumption that the risk-bearers have the capacity to respond to the information conveyed to them, including the capacity to select other options in altering their behavior - which can result in disparate burdens to subsistence community.

To the extent that it is complementary to risk reduction, fish advisory warning can help achieving environmental justice goals ${ }^{39}$ by taking into account some concerns. ${ }^{40}$ First, the message content needs to (i) include the nature, extent and sources of contamination; ${ }^{41}$ (ii) identify and take into account different groups and sub-groups in the community. ${ }^{42}$ Second, the medium and distribution of information: (i) must suit the needs of the community; ${ }^{43}$ (ii) must be provided in language of the affected community (including oral traditions); and (iii) must be accessible (a simple language which avoids jargon and uses visuals). ${ }^{44}$ Third, agencies should evaluate effectiveness of the advisory warning, particularly on the outcomes on particular products; the outcomes on awareness; behavioral outcome; and more broadly crafted outcomes. ${ }^{45}$

\section{What the Existing Laws Say about Fish Advisory Warning}

This section examines some existing tools which support the notion that the government have an obligation to gather information regarding mercury contamination in fish and, if appropriate, issue fish advisory warning. The relevant authorities are:

\section{A. Fishery Law}

Although one of the objectives set by the Fishery Law is to increase fish quality, ${ }^{46}$ no single provision in the statute speaks about using informational tools with regard to fish safety. The Fishery Law primarily takes the command and control approach, ${ }^{47}$

environmental decision-making process because "more people can participate in the policy dialogue on any and every scale," see Esty, op.cit., at 169.

${ }^{38}$ See Renshaw, op.cit., p. 660.

${ }^{39}$ O’Neill, op.cit., pp.23-25.

40 NEJAC, op.cit., p. 107-9.

${ }^{41}$ The rationale of the proposal to include this content is to empower the affected community to "take action to reduce pollution sources and clean up existing contaminated sites or obtain financial compensation for the loss of the natural resources." See "National Risk Communication Conference," Proceedings Document 1-11 (2001), cited in NEJAC, op.cit., p. 117.

${ }^{42}$ As noted in the NEJAC assessment, this also includes the needs of any subgroups within the larger group, such as nursing infants, children, pregnant women and women of childbearing age, elders, traditionalists versus modernists in terms of practices that implicate fish consumption, and subgroups defined by geographical region. See Ibid., p. 117.

43 NEJAC assessment in one of the impacted subsistence communities in San Francisco Bay Area indicated that most people assessed (nearly 60\%) obtain the information through television news, followed by direct communication with friends and families (37.8\%), signs at various piers (18.9\%), newspapers (14.4\%), and the rest heard it through church, local community-based organization, school, doctor's office, and the welfare office. See Id., at 120-122; see also Audrey Chiang, Asian Pacific Environmental Network, $A$ Seafood Consumption Survey of the Laotian Community in West Contra Costa County, California 30 (1998).

${ }^{44}$ Ibid., pp. 117-120.

${ }^{45}$ Ibid., pp. 123-125.

${ }^{46}$ Art. 3(f) of the Fishery Law, supra note 46.

47 The Fishery Law establishes the quality assurance and safety system for fishery products, and states three subsystems as a part of that: (1) monitoring and control of quality; (2) standard setting for, inter alia, product quality and testing method; and (3) certification. See Art. 20(2) of Fishery Law., Ibid. 
requiring "anyone who handles and processes fishery products" to meet the quality assurance and fish safety requirements. ${ }^{48}$ The agency will issue a certificate for those who meet the requirements ${ }^{49}$ and anyone who does not comply with the handling and processing requirements is subject to criminal prosecution..$^{50}$ As set out in its implementing regulation, the enforcement of these provisions relies exclusively on the inspection, verification, survey, and sample collection ${ }^{51}$ of certain criteria, including contaminants in the fish. ${ }^{52}$

The statute mandates the government to establish and develop an information and statistic data system regarding fishery, including data collection, processing, analysis, storage, presentation, and dissemination. ${ }^{53}$ However, the information mandated does not cover fish safety concern and is written rather as an exclusive list than a minimum requirement. ${ }^{54}$ Until now, there is no government regulation or any other implementing regulations specifically regulating such information system.

\section{B. Food Law}

Although the Food Law expressly mandates the central and local governments to guarantee food safety ${ }^{55}$ and increase the quality of food consumption by developing the people's knowledge and capacity in safe consumption pattern, ${ }^{56}$ the statute does not have a specific mandate on the use of fish advisory warning. The statute, however, expressly imposes the obligation on the government to establish food safety and quality standards $s^{57}$ both for fresh and processed food, ${ }^{58}$ and give warranty for foods complying with the standards. ${ }^{59}$ Anyone who produces and sells ${ }^{60}$ food, including fishermen and fish farmers, must comply with the standards. ${ }^{61}$

${ }^{48}$ Art. 20(3) of Fishery Law, Ibid.

49 There are two types of certificate related to fish safety: (1) for the processing, Processing Eligibility Certificate; and (2) for the quality assurance, Integrated Quality Management Program Implementation Certificate. See Art. 20(4) and Art. 20(5).

${ }^{50}$ The criminal provision imposes a maximum of one year imprisonment and a fine of IDR 800 million (around US\$ 62,400), see Art. 89 of Fishery Law, Ibid.

${ }^{51}$ Regulation of Ministry of Maritime Affairs and Fishery No. PER,19/MEN/2010 regarding Control of Fishery Products Quality Assurance and Safety System ("MMAF Regulation”), Art. 10.

${ }^{52}$ Other monitored criteria include medicine residual, chemical substances, biological materials, food, contaminants, microbiology, organoleptic, biotoxin and histamine. See Art. 18(1) of MMAF Regulation, Ibid.

53 Art. 46(1) of Fishery Law, Ibid.

${ }^{54}$ The statute requires information and data related to the potential, infrastructure, production, handling, processing and marketing of fish, and the economic and social data related to the implementation of fishery resources management and development of fishery business system. Ibid.

${ }_{55}$ The Food Law defines "food safety" as the necessary condition and measures needed to prevent food from the possibility of biological, chemical, and other pollutions which might disturb, harm, and endanger human health [...] therefore safe for consumption" see Art. 1(5) of the Food Law, supra note 48.

${ }^{56}$ Art. 59 of the Food Law, Ibid.

${ }^{57}$ The Food Law specifies the means the government must pursue in realizing food safety, two of which are relevant to this issue: (1) to establish standards for food packaging; and (2) to give food safety and quality warranties in compliance with the standards. See Art. 69 of the Food Law, Ibid.

${ }^{58}$ Fresh food is subject to the requirements set in "Fresh Food Safety and Quality," and produced food is subject to "Food Safety and Quality" standards. The statute does not clearly states, however, how the two concepts relate and possibly overlap. See Art. 88(1), Ibid.

59 Ibid.

${ }^{60}$ As for sellers, it points specifically to the producer's and the seller's obligation to comply with the Food Safety and Quality standards. See Art. 86(1) and (2) of the Food Law, Ibid.

${ }^{61}$ See Art. 86(2) and Art. 88(1) of the Food Law, Ibid. 
Indonesia's standard for mercury ${ }^{62}$ is set in $0.5 \mathrm{mg} / \mathrm{kg}$ for fish and fish products, ${ }^{63}$ and $1.0 \mathrm{mg} / \mathrm{kg}$ for predatory fish (such as swordfish, tuna and marlin), shellfish and mollusk, and shrimp and other crustaceans. ${ }^{64}$ The standard is applicable equally to fresh fish and processed fish, ${ }^{65}$ and according to the Food Law, all food containing contaminants above the maximum standard is considered as "contaminated food." 6 The statute prohibits "anyone from distributing contaminated food," ${ }^{\prime 7}$ and imposes an administrative sanction on the violator, ${ }^{68}$ either in the form of fine, injunction, withdrawal of food, damages, and/or revocation of permit. ${ }^{69}$ The statute even goes further to consider the intentional violation as a criminal, subject to up to two years' imprisonment or a fine up to four billion rupiah. ${ }^{70}$

Despite the absence of an express statutory mandate, a possible legal basis for the agency to issue fish advisory warning on mercury-contaminated fish is the government's duty, ${ }^{71}$ through Food Data and Information Center, ${ }^{72}$ to "develop an integrated food information system.." ${ }^{73}$ One of the functions of the information system includes early warning system on "food problem," ${ }^{4}$ which is defined as a situation of deficiency, surplus, and/or inability of individuals or households in fulfilling the needs of food and food safety. ${ }^{75}$ Although the statute defines data and information to be provided by the information center is in a closed list that does not include food safety level, ${ }^{76}$ the language of the provision speaks in a "minimum" obligation.

The Food Data and Information Center is elaborated in further detail under Government Regulation No. 17 of 2015 regarding the Food Security and Nutrition ("Food Security GR"). ${ }^{77}$ Not much detail is provided regarding the content or mechanism in disclosing food quality or contamination problem, but the regulation

\footnotetext{
62 The SNI does not regulate mercury and methyl-mercury separately. See Ibid.

${ }^{63}$ Indonesian National Standards (Standar Nasional Indonesia, hereinafter referred to as "SNI") for the Maximum Level of Heavy Metal Contamination in Food, SNI 7387:2009 (2009), p. 5.

${ }^{64}$ However, the SNI does not provide further guidance whether or not the products derived from predatory fish, shellfish and shrimp must follow the $0.5 \mathrm{mg} / \mathrm{kg}$ standard for "fish and fish product" or the 1.0 $\mathrm{mg} / \mathrm{kg}$ standard. See Ibid.

${ }^{65}$ See Ibid.

66 Art. 90(2) of the Food Law, Ibid.

${ }^{67}$ Art. 90(1) of the Food Law, Ibid.

${ }^{68}$ Art. 94(1) of the Food Law, Ibid.

${ }^{69}$ Art. 94(2) of the Food Law, Ibid.

${ }^{70}$ Art. 140 is applicable for "anyone who intentionally produces and trades food which does not fulfill the Food Safety standards as provided in Art. 86(2)," Four billion rupiah equals to US\$333,333.34; see Art. 140 of Food Law, Ibid.

71 The Law sets out the duty of the government and local government to "establish, manage, and develop" an integrated Food Information System. Art. 114(1) of the Food Law, Ibid.

72 See Art. 115(1), (2) and (3), Ibid.

${ }^{73}$ Food Information System including the collection, tabulation, analysis, retention, presentation, and dissemination of data and information regarding food. See Art. 133 of Food Law, Ibid.

${ }^{74}$ See Art. 114(2), Ibid.

75 Art. 1(28) of the Food Law, Ibid.

76 Art. 115(3) states "Food Data and Information Center provides data and information at minimum regarding the type of food product, food balance, location and measurements of food production area, market demands, opportunity and challenge of the market, production, price, consumption, nutritional status, export and import, estimate of supply, forecast of planting and harvesting season, climate forecast, food technology, the need of food in each area." See Art. 115(3) of the Food Law, Ibid.

77 Indonesia, Peraturan Pemerintah No. 17 Tahun 2015 tentang Ketahanan Pangan dan Gizi (Government Regulation regarding Food Security and Nutrition), PP No. 17 Tahun 2015, LN No. 60 Tahun 2015 ("Food Security GR")
} 
provides more details on data collection, analyses, storage and documentation, as well as dissemination of the data. ${ }^{78}$ The institution tasked to implement the system is also specified, which is the Food and Drugs Agency in the central, provincial and regency/ city level. ${ }^{79}$ Another useful reference is related to how the data and information must be delivered to the public: promptly, appropriately, and accurately. ${ }^{80}$ Even though the GR requires the information system to follow the norms, standards, procedure and criteria to be set in the implementing (lower hierarchy) regulation, to date, the Head of Food and Drugs Agency has not issued the required decree.

Another existing regulatory tool is the mandatory label in food products, ${ }^{81}$ which is especially useful for processed fish. However, no warning requirement related to the contaminant level in fish products is mandated in the minimum requirement, ${ }^{82}$ even though other provision requires the information in the label 'relates' to safety of the food..$^{83}$

\section{Environmental Protection and Management Law ("EPML")}

Built upon the constitutional right to a healthy and sound environment, ${ }^{84} \mathrm{EPML}$ expressly affirms the right to environmental education, access to information, participation and justice for everyone. ${ }^{85} \mathrm{In}$ its explanatory note, the statute defines 'environmental information' broadly, including data, explanation, or other information related to protection and management of environment the nature and objective of which is open for public. ${ }^{86}$ EPML further mandates the central government and the local government to develop an integrated and coordinated environmental information system $^{87}$ which shall be published for public. ${ }^{88}$ The statute defines the minimum content of the information system, which must include, at minimum, environmental status, environmental hazard map, and other environmental information. ${ }^{89}$ However, the government regulation or the Decree of Ministry of Environment and Forestry on

${ }^{78}$ See Art. 78-82 of Food Security GR, Ibid.

79 See Art. 83 of Food Security GR, Ibid.

${ }^{80}$ See Art. 84 of Food Security GR, Ibid.

81 The labeling requirement mandates "anyone who produces food domestically for the commercial purpose must put on a label inside and/or on the package of the food product," see Art. 97(1) of the Food Law, Ibid.

82 The mandatory labeling requirements include the name of product, list of ingredients, net weight/ volume, name and address of producer/importer, "halal" requirement, date and code of production, expiry date, number/code of distribution permit, origin of certain food ingredients. See Art. 97(3) of the Food Law, Ibid.

${ }^{83}$ Art. 96(2) of the Food Law, Ibid.

${ }^{84}$ The textual formulation of Article $28 \mathrm{H}$ para. (1) incorporates the 'right to obtain and enjoy an environment that is sound and healthy' in line with the right to 'live with physical and mental welfare, right to settle, and right to obtain health service'. See Indonesia, the 1945 Constitution of the Republic of Indonesia, Art. 28H; see also Constitutional Court, the Republic of Indonesia, Comprehensive Text of Book VIII of Indonesian 1945 Constitution (2010)

${ }_{85}$ See Art. 65(2) of EPML, op.cit. EPML even extends the traditional obligation to fulfill such right beyond the state, expressly incorporating the obligation of "anyone who conducts business and/or activity," which encompasses the state, quasi state (i.e. state-owned companies), to private actors, to give information related to the protection and management of environment truthfully, accurately, openly, and timely. See Art. 68, Ibid. Further, Art. 30(2) of EPML expressly recognizes the "right to obtain information regarding water quality status and water quality management and water pollution control," see Art. 30(2) of EPML.

${ }^{86}$ Explanatory note of Art. 62(2) of EPML, Ibid.

${ }^{87}$ Art. 62(1) of EPML, Ibid.

${ }^{88}$ Art. 62(2) of EPML, Ibid.

${ }^{89}$ Art. 62(3) of EPML, Ibid. 
that information system is not yet in place, even though five years has passed since the deadline set by the law.

EPML's water pollution provisions also expressly mandate polluters ${ }^{90}$ to give pollution warning to the community as a part of their response action. ${ }^{91}$ EPML's implementing regulation ${ }^{92}$ obliges the government to give information to the people regarding water quality management and water pollution control..$^{93}$ It even extends to private actors, imposing obligation on "everyone conducting business and/or activity" ${ }^{\prime \prime}$ to give water pollution information.

\section{Public Information Disclosure Law ("PIDL”)}

PIDL is distinguishable from the other two statutes explained above, since it is a purely procedural statute, and its applicability encompasses all substantive laws like EPML and Food Law. ${ }^{95}$ PIDL mandates 'public bodies ${ }^{96}$ to immediately announce the information about matters which can threaten the lives of many people and the public order ("immediate information"), ${ }^{97}$ specifically mandating the disclosure to be in an accessible manner with an easily understandable language. ${ }^{98}$ Further, it imposes a criminal sanction ${ }^{99}$ on the public bodies which intentionally do not give the mandated information. ${ }^{100}$

The statute's implementing regulation, Information Commissioner Regulation No. 1 of 2010 ("IC Regulation") ${ }^{101}$ further specifies the information "includes, among others,"102 information regarding "non-natural disasters such as industrial/ technological failure, industrial impacts and environmental pollution"103 and information regarding "toxic within food consumed by people." ${ }^{104}$ The IC Regulation mandates "all public bodies which have authority over" 105 immediate information, and/or "public bodies which have authority to give permit and/or conclude a contract

90 The language used by the provision is "Everyone who pollutes [...] shall conduct pollution abatement. See Art. 53(1) of EPML, Ibid.

${ }_{91}$ Art. 53(2) of EPML, Ibid.

${ }^{92}$ Government Regulation No. 82 of 2001 regarding Water Pollution Control.

${ }^{93}$ Art. 33 of Water Pollution Control Regulation.

94 Art. 32 of EPML states "everyone conducting business and/or activity shall have an obligation to give truthful and accurate information regarding the implementation of the obligation regarding water quality and water pollution control," see Art. 32 of EPML, op.cit.

${ }_{95}$ As one of the principles in the civil law tradition, "legi generali derogal lex specialis," the general law will override the specific law, and therefore, considering the breath and procedural nature of the PIDL, to the extent it applies to information disclosure, PIDL will overridethe specific statute.

96 Public bodies are defined as "the executive, legislature, judiciary and other agencies whose main functions and duties are related to the state administration, of which a part or all of its funding resource is from the state budget and/or local government's budget, and or non-governmental organization as long as a part of all of the funding is from the state budget and/or local budget, public donation, and/or foreign donation," see Art. 1(3) of PIDL, op.cit.

${ }^{97}$ Art. $10(1)$ of PIDL, Ibid.

98 Art. 10 (2) of PIDL, Ibid.

99 A maximum of one year of imprisonment and/or a fine of IDR 5 million is to be imposed upon a public body which commits this crime, see Art. 52 of PIDL, Ibid.

100 Art. 52 is not only applicable for non-disclosure of immediate information, but also for non-disclosure of other categories of information, see Ibid.

${ }^{101}$ Information Commissioner Regulation no. 1 of 2010 ("IC Regulation"), op.cit.

102 Art. 12(2) of PIDL, Ibid.

103 Art. 12(2)(b) of PIDL, Ibid

104 Art 12(2)(e) of PIDL, Ibid.

105 Art 12(1) of PIDL, Ibid. 
with another party whose activity has the potential to threaten the lives of people and public order"106 to establish standards of disclosure of the immediate information. ${ }^{107}$ The standards at issue is substantive rather than procedural, governing the minimum content of the information to be published, including potential danger and/or magnitude of harm which can be caused, ${ }^{108}$ parties which are potentially impacted, ${ }^{109}$ and how to avoid the danger and/or its impact, ${ }^{110}$ and the measures taken by the public bodies and/or authority in mitigating the danger and/or its harm. ${ }^{111}$

\section{Opportunities and Challenges of the Existing Laws}

The fact that no single regulation on fish advisory warning is in place in Indonesia can be either an opportunity or a challenge. The present legal framework has some serious challenges, but allows government to issue fish advisory warning as discretion.

\section{A. Challenges: the Needed Reforms}

As mentioned briefly above, the present legal framework has some serious flaws, especially since it does not take into account consumption beyond commerce, ${ }^{112}$ including by subsistence community. Nothing in the present food laws and regulations gives guidance to direct consumers, whether it's subsistence or recreational, to know the safety of their catch, and the safe frequency of fish consumption in their diet. Further, the standard does not take into account different the susceptibility and patterns of consumption, raising another environmental justice concern. ${ }^{113}$ The regulatory scheme also relies heavily on the government inspection and market compliance, ${ }^{114}$ and no measure is in place to guide consumers when the government or market fails to ensure compliance. Considering the low effectiveness of rule of law in Indonesia, there is still a high possibility that even the regulated fish in commerce that ends up in consumer's plate is not safe. ${ }^{115}$ Most importantly, by relying heavily on the government and market, the statutes neglect the consumer's role in altering their consumption pattern and making conscious choices, which may influence the industries in terms of compliance. ${ }^{116}$

106 Ibid.

107 Ibid.

${ }^{108}$ Art. 12(3)(a), Ibid.

109 Art. 12(3)(b), Ibid.

110 Art. 12(3)(d), Ibid.

111 Art. 12(3)(h), Ibid.

112 The prohibition set out in the statute is merely for "production and distribution/trade," so it does not say anything about consumption. Therefore, direct consumption by subsistence community wholly escapes the regulation. The statute itself does not expressly state that it only regulates "food in commerce," but none of its provisions actually regulates things beyond commerce. See the Food Law, Ibid.

113 See Clifford Rechtschaffen, Eileen Gaune and Catherine O'Neill, Environmental Justice: Law, Policy and Regulation, $2^{\text {nd }}$ Edition (2009).

${ }^{114}$ For example, Art. 92 mandates the government and/or the local government to conduct supervision and prevention periodically towards the level of contaminants in food. See Article 92 of the Food Law, Id. See also Article 86(2) and 88(1) of the Food Law, Ibid.

115 Indonesia ranked $107^{\text {th }}$ in the Transparency International's Corruption Perception Index 2014, see Transparency International, CPI, available at https://www.transparency.org/cpi2014/results; Moreover, according to World Bank's World Governance Indicators, Indonesia's regulatory quality for 2013 scored $46 / 100$, governance effectiveness $45 / 100$, rule of law $36 / 100$, and control of corruption $32 / 100$. See World Bank, Worldwide Governance Indicators, available at http://info.worldbank.org/governance/wgi/index. aspx\#reports, accessed on 29 March 2015.

116 See Renshaw (2006), op.cit, p. 660. 


\section{B. Opportunity and Strategy to Use the Existing Laws}

As the existing legal framework emphasizes direct alteration of the risk, fish advisory warning fits perfectly as a complement of the existing statutory mandate and authority. ${ }^{117}$ Fish advisory warning can contribute in remedying these challenges by equipping the risk bearers to alter their behavior by giving options to avoid the risk. ${ }^{118}$ Each substantive statute elaborated above contains specific mandates to create information system; however, the mandated information system is for different purposes, with a different scope of authority. ${ }^{119}$ Three issues are related to this, the first one is whether the agencies have the statutory duty or discretionary authority to issue fish advisory warning.

The Fishery Law ${ }^{120}$ and the Food Law ${ }^{121}$ mandate agencies to ensure the fish consumed by the people to be safe from mercury contaminant above the acceptable level. ${ }^{122}$ Both statutes do not expressly mandate the use of fish advisory warning, yet allow agencies to have discretion to use fish advisory warning to achieve food safety in fishery products. The Fishery Law, primarily administered by the Ministry of Maritime Affairs and Fishery ("MMAF"), ${ }^{123}$ has the weakest statutory authorization for fish advisory warning, as the Fishery Information and Statistic Data System does not cover fish safety concern, ${ }^{124}$ while the required information is written in a closed list. ${ }^{125}$ Consequently, the agency has only the discretionary authority to issue fish advisory warning under the statute. ${ }^{126}$

The Food Law also only gives a vague mandate through the Food Information System's early warning on food problem. ${ }^{127}$ Arguably, if the mercury contamination problem in fish falls under the definition of "food problem,"128 the government has a statutory obligation to go beyond its minimum list of warning information and issue fish safety information as a part of its early warning system. ${ }^{129}$ The authority in safeguarding mercury level in fish for human consumption under the Food Law is the Indonesia's food and drugs agency ("BPOM"). ${ }^{130}$ Even if BPOM lacks a statutory mandate, it has the discretionary authority to issue fish advisory warning in light

117 Renshaw noted four policy options to manage risky product: (1) maintain status quo, leave risk management to market; (2) ban the product entirely; (3) directly alter the risk; (4) adopt warning program, see Renshaw, op.cit, p. 663.

118 See Ibid., p. 660.

119 See the Fishery Law, op.cit; the Food Law, op.cit; EPML, op.cit.

120 See Art. 20(3) of the Fishery Law, op.cit.

121 Art. 69 of the Food Law, op.cit.

${ }^{122}$ In this case, fish and fish products must not contain mercury above $0.5 \mathrm{mg} / \mathrm{kg}$, and predatory fish, shellfish and mollusk, and ship and other crustaceans must not contain mercury above $1.0 \mathrm{mg} / \mathrm{kg}$. See SNI for the Maximum Level of Heavy Metal Contamination in Food, op.cit.

123 See Regulation of Ministry of Maritime Affairs and Fishery No. PER.15/MEN/2010 regarding the Organization and Governance in Ministry of Maritime Affairs and Fishery.

${ }_{124}$ See Art. 46(1) of the Fishery Law, op.cit.

125 Art. 46(1) of the Fishery Law, op.cit.

${ }^{126}$ Indonesia defines discretion as "decisions and/or actions set out and/or carried out by government officials to address concrete problems encountered in the implementation of the government when the legislation gives the option, silent, incomplete or unclear, and/or in a situation in which the government stagnation takes place." See Law No. 30 of 2014 regarding Governance Administration, op.cit., Art. 1(9).

127 See Art. 114(2) of the Food Law.

128 See Art. 133(1) and (2) of the Food Law., op.cit.

129 See Art. 115(3) of the Food Law, supra note 75, 79.

130 Badan Pengawas Obat dan Makanan ("BPOM") is regulated under Law No. 18 of 2012 regarding Food, op.cit. 
of the statute's objective to guarantee food safety ${ }^{131}$ and increase the quality of food consumption by educating people. ${ }^{132}$ The Food Law is particularly useful for regulated market or fish in commerce, ${ }^{133}$ but, as elaborated above, has a serious flaw for reaching the subsistence community.

The last substantive statute, EPML, administered by the Ministry of Environment and Forestry ("MOEF"), ${ }^{134}$ can possibly fill this gap since it guarantees environmental education and access to information as a matter of right. ${ }^{135}$ It is supported with the broad definition of environmental information ${ }^{136}$ and a mandate to provide 'other environmental information' in the information system. ${ }^{137}$ A possible solution to remedy the defect in the Fishery Law and Food Law is by providing fish advisory warning along the mercury contaminated water bodies as a part of the environmental information system. However, with such a broad obligation, whether or not such informational approach is to be provided is within the agency's discretion.

Reading each statute in light of PIDL, in addition to their discretionary duty, each agency has a statutory obligation as a public body to provide immediate information. ${ }^{138}$ Mercury contamination in fish is arguably qualified as a situation threatening the lives of many people ${ }^{139}$ by low-amount long-term exposure. Therefore, each of the agencies, under their specific authority, has a general obligation to provide information as specified in the IC Regulation, ${ }^{140}$ especially the potential of danger of the methyl-mercury in fish the measures to avoid it, ${ }^{141}$ including to vulnerable groups. ${ }^{142}$ The obligation might even extend beyond fish advisory warning since it mandates the information to include the measures taken by public bodies in mitigating the danger. ${ }^{143}$ This last substantive obligation contemplated by PIDL and IC Regulation is progressive, visioning a risk avoidance strategy which supports risk reduction. ${ }^{144}$ Therefore, the role of fish advisory warning should be rather temporary and complementary than replacing risk reduction and the agency must not refrain from taking measures to mitigate the sources of mercury contamination. ${ }^{145}$

The second issue would be a problem of political scale, ${ }^{146}$ especially regarding the division and coordination of different agencies' role and authority. At a minimum, fish advisory requires agencies to coordinate related to data collection and tabulation

131 See Art. 1(5) of the Food Law, op.cit.

132 See Art. 59 of the Food Law, op.cit.

${ }^{133}$ Although it is not expressly stated that the scope of the statute is limited to commercial fishery, all provisions in the statute regulate fish in market and speak nothing of non-market fish use. See the Food Law, op.cit.

${ }^{134}$ See Presidential Regulation No. 16 of 2015 regarding Ministry of Environment and Forestry

135 See Indonesia, Presidential Regulation No. 16 of 2015 regarding Ministry of Environment and Forestry.

136 See explanatory note of Art. 62(2) of EPML, op.cit.

137 Art. 62(3) of EPML, Ibid.

138 See Art. 10(1) of PIDL.

139 See Art. 10(2) of PIDL.

140 See IC Regulation, op.cit.

141 See Art. 12(3)(d) of PIDL.

142 The IC Regulation especially mandates immediate information to identify the parties who are potentially impacted. See Art. 12(3)(b) of PIDL.

143 See Art. 12(3)(h) of PIDL.

144 See O’Neill (2003), op.cit, pp. 5-7.

145 See Art. 12(1), (2) and (3) of the IC Regulation, op.cit.

${ }^{146}$ For a comprehensive discussion about scale, see James Rasband, James Salzman, and Mark Squillace, Natural Resources Law and Policy, (Eagan, MN: Foundation Press, 2d ed., 2009), pp. 36-62. 
of fish tissue database and methodology to set a safe fish consumption rate. ${ }^{147}$ As mentioned above, each agency has a different role and authority to administer a different statutory mandate under a different information system, ${ }^{148}$ and a possibility of overlapping role. In the national level, MMAF, BPOM and MOEF have some options in dividing and coordinating their respective roles.

As elaborated above, data collection authority can be found both under the Fishery Law, the Food Law, and EPML, all as a matter of discretion. However, the Fishery Law and the Food Law give stronger authority for collecting information regarding mercury-contaminated fish in commerce, ${ }^{149}$ and EPML for the direct consumption associated with the water pollution. Having that in mind, for the data collection, the first option is to maintain the different statutory mandates in collecting and managing the data regarding mercury contamination in fish. For fish and fish products which go into the market, MMAF and BPOM extract the data from their present inspection authority and collaborate in their analysis. ${ }^{150}$ As for water body, MOEF needs to start building comprehensive data on mercury levels in fish in all water bodies. ${ }^{151}$ The second option is to form a joint task force consisting of the three agencies since the data collection phase. The three agencies can issue a joint ministerial regulation on fish advisory warning, ${ }^{152}$ appointing the leading agency, or detailing the work division and coordination. As for the formulation of the advisory content and dissemination of the advisory, a joint effort such as EPA/FDA joint advisory ${ }^{153}$ is necessary, since it will give a significant advantage to avoid redundancy and a more comprehensive perspective regarding different stakeholders' interests. ${ }^{154}$ The scale problem needs more careful consideration in the information dissemination, as effective dissemination to reach risk bearers on the ground will likely rely primarily on the role of local governments. ${ }^{155}$ The advisory must reach beyond doctors' offices and online dissemination, and the national-local coordination concern is especially true on the advisory warning along the river, which may involve placement of physical signs, and the warnings in the point of sale. ${ }^{156}$ Bearing in mind the different organization, management, and working culture between the national and local government in each agency, ${ }^{157}$ the agencies must identify the division of roles and cooperation both between the national and local government, and the different agencies in the local government. ${ }^{158}$

${ }_{147}$ See EPA, EPA Technical Memorandum: Origin of 1 Meal/week, available at http://water.epa.gov/scitech/swguidance/fishshellfish/outreach/upload/2004 0721 fish advice 1-meal-per-week.pdf accessed on 30 March 2015.

${ }^{148}$ See Fishery Information and Statistic Data System, see Art. 46(1) of the Fishery Law, supra note 56 and 57; Food Information System, Art. 114(2) of the Food Law; Environmental Information System, Art. 62(1) of EPML.

149 The Food Law, op.cit.

150 See Art. 46(1) of the Fishery Law; see also Art. 115(1), (2), and (3), op.cit.

151 See Art. 62(1), (2) and (3) of EPML, op.cit.

152 The lesson learned from EPA and FDA, which previously issued a different fish advisory warning under their own regulation, provide a valuable lesson to take a comprehensive approach in issuing advisory warning since the planning process. See O'Neill, op.cit.

153 EPA/FDA Advisory, op.cit.

154 See Southerland, op.cit.

155 See ICEL, Strengthening the Right of Information for People and the Environment (STRIPE) Final Report: Case Study from Indonesia (Jakarta: ICEL, 2013), at 55-6.

156 See Renshaw, op.cit, at 683.

157 See Rasband, Salzman, and Squillace, op.cit.

158 The local government and the national government have a relationship like a cooperative federalism based on Law No. 32 of 2004 regarding the Local Government. Simply put, the relationship is based on local autonomy, with programs set out by the national government as a minimum requirement, as well 
The third issue is directly related to the role of fish advisory to advance environmental justice. Without environmental justice concern, the content at minimum must be able to tell risk bearers about the types of fishes to be avoided completely, allowable consumption on fishes, the local or water body-specific fish advisory, and how to response non-existence of specific advisory. ${ }^{159}$ In addition to that, the information related to the nature, extent and sources of the relevant contamination and risk and health effects must be made available. ${ }^{160}$ As discussed above, the standard set by PIDL and the IC Regulation provides an opportunity to ensure the content of the advisory answers the need of environmental justice of the community by mandating mitigation efforts in risk reduction, ${ }^{161}$ but beyond that, it is subject to the agencies' discretion. As choosing the right and effective language is also important in issuing advisory, ${ }^{162}$ such additional information does not necessarily have to be within the warning, but it can be complementary to it.

\section{Conclusion}

This paper concludes that Indonesian law implies a statutory mandate for the government to issue fish advisory warning, at least in a situation involving the threat to general life - not specifically through the Fishery Law, Food Law, or EPML, but through PIDL's immediate information mandate. However, House of Representative leaves broad discretion for the agency to determine how and to what extent such a mandate will be carried out. In its discretion, agencies need to consider: (1) how to harmonize statutory mandates of all relevant statutes with its policy choice in issuing fish advisory warning; (2) how to divide and coordinate different agencies' roles, both between the national and local government and between different agencies in horizontal level, starting from the data collection, establishment of methodology, until the information dissemination; and (3) how to ensure the policy advances environmental justice concern and support risk reduction measures.

\section{Bibliography}

\section{Legal Documents}

Indonesia. Information Commissioner Regulation No. 1 of 2010 regarding Public Information Service Standard.

- - - Peraturan Pemerintah tentang Keamanan, Kualitas dan Nutrisi Pangan (Government Regulation regarding Safety, Quality and Nutrition of Food). PP No. 28 Tahun 2004 (GR No. 28 of 2004).

- - - Peraturan Pemerintah tentang Pengelolaan Kualitas Air dan Pengendalian Pencemaran Air (Government Regulation regarding Water Quality Protection and Water Pollution Control). PP No. 82 Tahun 2001, LN No. 153 Tahun 2001 (GR No. 82 of 2001, SG No. 153 of 2001).

as the standard where the national standard will be the foundation. See Law No. 32 of 2004 regarding the Local Government.

159 See Renshaw, op.cit., p. 682.

160 O'Neill, op.cit., at 23.

161 See Art. 12(1), (2) and (3) of the IC Regulation, op.cit.

162 Rensaw noted that it is necessary to find a language which does not scare people away from fish consumption, but can effectively inform people to reconsider their fish choices and method of cooking. See Renshaw, op.cit., p. 683. 
The 1945 Constitution of the Republic of Indonesia, the Fourth Amendment. 1945.

. Undang-Undang tentang Administrasi Pemerintahan (Law regarding Governance Administration). UU No. 30 Tahun 2004 (Law No. 30 of 2014).

. Undang-Undang tentang Kesehatan (Law regarding Health). UU No. 36 Tahun 2009, LN No. 144 Tahun 2009 (Law No. 36 of 2009, SG No. 36 of 2009).

. Undang-Undang tentang Keterbukaan Informasi Publik (Law regarding Public Information Disclosure). UU No. 14 Tahun 2008, LN No. 4846 Tahun 2008 (Law No. 14 of 2008, SG No. 4846 of 2008).

. Undang-Undang tentang Pangan (Law regarding Food). UU No. 18 Tahun 2012, LN No. 227 Tahun 2012 (Law no. 18 of 2012, SG No. 227 of 2012).

- - - Undang-Undang tentang Perikanan (Law regarding Fishery). UU No. 31 Tahun 2004, LN No. 154 Tahun 2009 (Law No. 31 of 2004, SG No. 154 of 2009).

- - - Undang-Undang tentang Perlindungan dan Pengelolaan Lingkungan Hidup (Environmental Protection and Management Law). UU No. 32 Tahun 2009, LN No. 140 Tahun 2009 (Law No. 32 of 2009, SG No. 140 of 2009).

. Undang-Undang tentang Perlindungan Konsumen (Law regarding Consumer Protection). UU No. 8 Tahun 1999, LN No. 42 Tahun 1999 (Law No. 8 of 1999, SG No. 42 of 1999).

Ministry of Health Regulation No. 2 of 2013 regarding Food Poisoning Outbreak.

Ministry of Maritime Affairs and Fishery Regulation No. PER.15/MEN/2010 regarding the Organization and Governance of Ministry of Maritime Affairs and Fishery.

- - - MMAF Regulation No. PER.19-MEN-2010 regarding Control of Quality Assurance System and Fishery Products Safety ("MMAF Regulation").

- - Regulation of Ministry of Maritime Affairs and Fishery No. PER,19/MEN/2010 regarding Control of Fishery Products Quality Assurance and Safety System.

\section{Books}

Chiang, Audrey. A Seafood Consumption Survey of the Laotian Community in West Contra Costa County. Report of the Asian Pacific Environmental Network (APEN). California, Asian Pacific Environmental Network: 1998.

Constitutional Court, the Republic of Indonesia. Comprehensive Text of Book VIII of Indonesia 1945 Constitution. 2010.

Dewi, Kania and Ismawati, Yuyun. Inventory of Mercury Releases in Indonesia. Denpasar: Balifokus, 2012.

EPA Office of Water. Guidance for Assessing Chemical Contaminant Data for Use in Fish Advisories, Volume IV: Risk Communication 10.1995.

NEJAC. Fish Consumption and Environmental Justice. Report Developed from the National Environmental Justice Advisory Council Meeting, December 3-6, 2001. Seattle: National Environmental Justice Advisory Council, 2001.

Glassburner, Bruce. The Economy of Indonesia: Selected Reading. Sheffield: Equinox Publishing, 2007.

Hadden, Susan G. A Citizen's Right to Know: Risk Communication and Public Policy. Boulder, CO: Westview Press, 1989.

ICEL. Strengthening the Right of Information for People and the Environment (STRIPE) Final Report: Case Study from Indonesia. Jakarta: ICEL, 2013.

Indonesian Center for Environmental Law. Study on Mercury Regulation in Indonesia. Jakarta: ICEL, 2012. 
Ismawati, Yuyun. Policy Brief: ASGM in Indonesia. Denpasar: BaliFokus, 2010.

NEJAC, Fish Consumption and Environmental Justice. New Jersey: 2002.

Office of Air Quality Planning and Standards \& Office of Research and Development, US EPA. Mercury Study Report to Congress, Volume 1: Executive Summary. EPA452/R-97-003. 1997.

Office of Water, EPA. "Guidance for Assessing Chemical Contaminant Data for Use in Fish Advisories." Volume IV: Risk Communication 10.

Pusat Kebijakan Regional dan Bilateral Kementerian Keuangan RI dan Program Studi Kajian Wilayah Eropa Program Pascasarjana Universitas Indonesia. Kajian Kerja Sama Bilateral Indonesia - Uni Eropa: Bidang Ekonomi dan Keuangan [Study on Bilateral Partnership between Indonesia - European Union: Economic and Financial Area]. Jakarta, Pusat Kebijakan Regional dan Bilateral Program Studi Kajian Wilayah Eropa Program Pascasarjana Universitas Indonesia, 2012.

Rasband, James; Salzman, James; and Squillace, Mark. Natural Resources Law and Policy. $2^{\text {nd }}$ ed. St. Paul, MN: Foundation Press, 2009.

Rechtschaffen, Clifford, Eileen Gaune, and Catherine O'Neill. Environmental Justice: Law, Policy and Regulation. $2^{\text {nd }}$ Edition. Durham, NC: Carolina Academic Press, 2009.

UNEP. Global Mercury Assessment 2013: Sources, Emissions, Releases and Environmental Transport. Geneva: UNEP Chemicals Branch, 2013.

\section{Articles}

Castilhos, Zuleica C., et. al. "Mercury Contamination in Fish from Gold Mining Areas in Indonesia and Human Health Risk Assessment," Science of the Total Environment 368, issue 1 (September, 2006): 320-325.

Esty, Daniel C. "Environmental Protection in the Information Age." NYU Law Review 79, (2004): 117-209.

O’Neill, Catherine. “No Mud Pies: Risk Avoidance as Risk Regulations.” Vermont Law Review 31 (2006-7): 273-326.

O’Neill, Catherine. "Risk Avoidance, Cultural Discrimination and Environmental Justice for Indigenous People." Ecology Law Quarterly 30, (2003).

Renshaw, Katherine. "Sounding Alarm: Does Informational Regulation Help or Hinder Environmentalism." NYU Environmental Law Journal 14 (2005-6).

Plunkett, David and Caroline Smith De Waal. "Who is Responsible for the Safety of Food in a Global Market? Government Certification v. Importer Accountability as Models for Assuring the Safety of Internationally Traded Foods." Food and Drug Law Journal 63 (2008): 657-664.

\section{Websites}

EPA. "EPA Technical Memorandum: Origin of 1 Meal/week." http://water.epa. gov/scitech/swguidance/fishshellfish/outreach/upload/20040721 fish advice 1-meal-per-week.pdf. Accessed on 30 March 2015.

EPA. "Risk Assessment: Basic Information." http://www.epa.gov/risk assessment/ basicinformation.htm\#a1. Accessed on 13 March 2015.

Southerland, Elizabeth. "Proceedings of the National Forum on Contaminants in Fish, May 6 and 9, 2001 1-10 (2001)." http://www.epa.gov/ost/fish/forum/fishforum.pdf. Accessed on $26 \mathrm{March}$ 2015. 
Transparency International. "Corruption Perception Index. https://www.transparency.org/cpi2014/results. Accessed on 25 March, 2015.

U.S. Dept. of Health and Human Service. \& U.S. EPA. "What You Need to Know About Mercury in Fish and Shellfish." http://www.epa.gov/waterscience/fishadvice/ advisory.pdf. Accessed on 24 March 2015.

United Nations Commodity Trade Statistic. "Mercury Trade Database." http:// comtrade.un.org. Accessed in March 2015.

World Bank. Worldwide Governance Indicators. http://info.worldbank.org/ governance/wgi/index.aspx\#reports. Accessed on 29 March 2015.

ZOI Environment Network. "Mercury Trade Map 2011." http://www.zoinet.org/web/ sites/default/files/publications/MercuryTradeMap2011.pdf. Accessed on March 25, 2015. 